\title{
Development of the Process Evaluation Model in IPS Integrated Learning Based on 2013-Curriculum
}

\author{
N Suraiya \\ Universitas Syiah Kuala: Dept \\ Economy Education \\ Banda Aceh, Indonesia \\ nana@unsyiah,ac,id
}

\author{
MOR Maulidian \\ Universitas Syiah Kuala: Dept \\ Geography Education \\ Banda Aceh, Indonesia \\ oktaridhageografi@unsyiah,ac,id
}

\author{
Nurmasyitah \\ Universitas Syiah Kuala: Dept \\ Elementary Teachers Education \\ Banda Aceh, Indonesa
}

\begin{abstract}
The research aims to develop a process evaluation model in Integrated IPS learning at Junior High School based on the 2013-Curriculum. This research development uses a method developed by Borg and Gall (1983). Subjects involved were teachers, principals, and students, who came from junior high schools in Aceh, including Banda Aceh, Aceh Besar, Bireuen, Aceh Tengah and Aceh Barat. Data was collected using a questionnaire and observation sheets. The development has been carried out in 3 stages, (1) Pre-Model Development (2) Model Development Phase and (3) Implementation (Model Testing). This testing model has been carried out in two stages, with the number of subjects increasing each stage. The Limited Test, has been conducted at 2 schools in Aceh Besar and Banda Aceh, with 4 social studies teachers, 2 school principals, and 50 students. The Extended Test has been carried out at 4 schools in Aceh Besar, Bireuen, Aceh Tengah, Aceh Barat, with 12 social studies teachers, 4 school principals, and 200 students. The results of the study produced a "Process Evaluation Model" in Integrated Social Studies learning in junior high schools, including; Evaluation Procedures, Evaluation Directory, and Evaluation Instruments. Based on the experimental results of the model, very good, comprehensive, practical, economical categories were obtained
\end{abstract}

Keywords-component; Process Evaluation, Integrated IPS Learning

\section{INTRODUCTION}

The Social Studies Learning Objectives in SMP from the National Council for Social Studies (NCSS) state that "the purpose of social studies (IPS) is to help students develop the ability to make rational decisions as citizens with diverse cultures, and democratic societies in a world that are interdependent [3]. The direction of teaching social sciences is to develop critical thinking skills and students' awareness and commitment to the development of society [8], social studies aim to develop social skills, attitudes, and skills [6]. Social studies learning has the aim to develop academic skills (academic skills), personal skills (personal skills) and social skills (social skills).

The objectives of the IPS in Indonesia have been outlined in the 2013 curriculum following Graduates Competency Standards and Content Standards. Standards Development Process includes Process Planning, Process Execution, Results Assessment and Monitoring Process in Learning. Evaluation of the achievement of learning objectives IPS needs to be done.
Evaluation of learning programs is carried out with a purpose or objective that is useful and targeted. There are four main uses for evaluation [7]:

a. Communicating the program to the public

The effectiveness of learning programs including those implemented in schools should be communicated to the public. If done in full, it will have benefits and benefits for teachers and schools. However, the general public, especially parents of students have an interest in learning in school. Schools should communicate the effectiveness of their learning programs to the public through the results of evaluations conducted so that the public can assess the effectiveness of learning programs and provide the necessary support.

b. Provides information for stakeholder

The information obtained from the evaluation of learning programs will be useful for each stage in school management, starting from the planning, implementation, or when going to restart and continue the program. Evaluation results can be the basis for stakeholder so that the decision is right, they need accurate information to be able to decide something right.

c. Completion of existing programs

Evaluation of the programs implemented will be able to help efforts to improve the learning program so that it is more effective. Through the identification of weaknesses and obstacles that are found can be found, analyzed, and then can be found the most appropriate alternative. Components that are still weak in the learning program can be studied and found a solution. Based on the evaluation results also obtained information about the impact of various aspects of the program on students, and identified various factors that need to be considered or need improvement. Program evaluation serves as the correction of errors or omissions learning program.

d. Increase participation

Information on the results of evaluations of learning programs allows parents or the community to participate and support efforts to improve the quality of learning. If done well, it will create a control that will stimulate and supervise the quality of learning. Besides, the evaluation also leads to increasing teacher motivation to improve their performance. Information about the results of the 
evaluation will confirm the components of the learning program which are weak and need to be improved. Information about learning achievements is also useful for increasing student motivation.

Based on the results of the survey, through observation and interviews with teachers in several junior high schools in the city of Banda Aceh, information was obtained that the Social Studies teacher did not conduct a Process Evaluation in integrated social studies learning properly. Social studies teachers do not plan, implement and evaluate social studies subjects correctly and comprehensively based on the 2013 curriculum. Therefore, this study will develop a Process Evaluation Model in social studies learning in junior high schools based on the 2013 curriculum.

\section{RESEARCH METHODS}

This research has used research and development methods which aim to create a product, namely a Process Evaluation Model in Integrated Social Studies learning in SMP based on 2013 Curriculum. The model was initiated by Borg\&Gall [4] with 10 steps, but in this study, it was shortened to 3 stages: 1) the pre-development stage of the model (2) the stage of developing the model and (3) the implementation stage (testing the model).

Analyzing data qualitatively is intended to analyze the validation data (design) by experts (judgment), which provides suggestions and opinions for improving evaluation procedures, evaluation directories, instruments and data about the effectiveness of the developed model. In addition, descriptive analysis was also carried out on the results of the implementation data (expanded test) to assess the quality of the implementation of the IPS integrated learning program in junior high schools in Aceh Province. The results are then converted in a qualitative form. Conversion of quantitative data into qualitative data [5].

Assessment of the procedures, instruments, and directories the evaluation model as a result of the development has been done by using a standard assessment in Table 2.1

TABLE I. CRITERIA FOR EVALUATING PROCEDURES, INSTRUMENTS, AND DIRECTORIES

\begin{tabular}{|c|c|l|l|}
\hline No & Score & \multicolumn{1}{|c|}{ Qualification } & \multicolumn{2}{|c|}{ Meaning } \\
\hline 1 & $>4.3$ & Very good & $\begin{array}{l}\text { Can be used as a } \\
\text { reference }\end{array}$ \\
\hline 2 & $>3,4-4,2$ & Good & $\begin{array}{l}\text { Can be used without } \\
\text { repair }\end{array}$ \\
\hline 3 & $>2,6-3,4$ & Acceptable & $\begin{array}{l}\text { Can be used with a little } \\
\text { improvement }\end{array}$ \\
\hline 4 & $>1,8-2,6$ & passed conditionally & $\begin{array}{l}\text { Can be used with many } \\
\text { improvements }\end{array}$ \\
\hline 5 & $>1,8$ & Fail & Can not be used \\
\hline
\end{tabular}

\section{RESULT AND DISCUSSION}

The development of the evaluation model that has been carried out regarding Borg\&Gall model, which is explained in three major stages, namely: the pre-development stage, the development phase and the trial phase of the model.

\section{A. Pre-development Stage}

The development of an evaluation model starts with examining theories, reviewing previous studies, gathering detailed information and gathering problems found in research in the field [2]. Activities that have been carried out: (1) The theoretical study and relevant research results are intended to find solutions to the main problems in the IPS Integrated learning process, whose findings are that there is no comprehensive and integrated evaluation model at the Junior High School level. (2). The survey has been conducted by visiting the school to find out the competence of teachers in the teaching and learning process, student enthusiasm, the condition of school facilities and infrastructure, also to find out how the evaluation process was carried out by the teacher. Then also several teachers and students were interviewed about the IPS integrated learning process. Based on the survey results, it can be determined that a comprehensive process evaluation model in the IPS integrated based on the 2013 curriculum needs to be developed.

\section{B. Development Stage}

In the next stage, we have designed a prototype model for program evaluation in IPS integrated learning in junior high schools, and have also prepared data collection instruments and evaluation model kits, as well as designs for evaluation trials. The evaluation model that has been developed was composed of three components, namely the evaluation procedure, evaluation instruments, and user directories.

\section{Trial Phase of the Model}

The trial phase of the model begins with validating designs that have been developed by users (social studies teachers) and experts. The draft was then revised based on the validator's suggestion, then the draft was tested directly in learning to obtain validation and reliability. This trial has been conducted with the aim of 1) to determine the suitability of the model and the accuracy of the evaluation model. 2) to find out whether the evaluation model instruments can evaluate IPS integrated learning in junior high schools.

\section{Model Trial Results}

The evaluation model components that have been validated by experts and users of the model consist of 1) evaluation components and procedures, 2) instruments with their lanes and 3) usage directories. The validation results obtained are as follows:

Before the trial, the prototype was first validated by experts (judgment). Trial procedures, instruments and evaluation directories have been carried out with Delphi techniques. The Delphi technique was an interactive and systematic forecasted based on individual feedback and selected values of one or more rounds. Proof of the validity of the contents of tests or instruments carried out by experts according to their fields [5]. 
How well the contents of these items represent the components in the overall object to be assessed or how the items reflect the behavior of the object [1].

This technique involves experts anonymously in responses, feedback to the group as a whole or individually. The experts are divided into 1). evaluation expert, 2). expert research methodology, 3). social studies education expert, 4). social studies teacher. This validation has been carried out by circulating an initial draft of the instrument (Likert scale) with certain answer choices. In addition to this, experts are also asked for advice and opinions on the sheets that have been provided.

\section{1) Assessment for the Evaluation Model Directories}

The assessment aspect for the evaluation directories focuses on the content and language used. This assessment includes: (1) clarity of general instructions, (2) clarity of evaluation steps, (3) clarity of steps and purpose of the evaluation results and (4) clarity of evaluation time (5) clarity of how to score, and (6) completeness fill in the directories. Also, language assessments include (1) sentence stiffness (2) sentences and words that are easily understood, (3) correct spelling and punctuation, (4) size and font used. The results of the validation can be considered in Table II.

TABLE II. RESUlts OF VALIDATION OF THE EVALUATION MODEL DIRECTORIES BY EXPERTS AND USERS

\begin{tabular}{|c|l|c|c|c|c|c|c|c|c|c|}
\hline No & $\begin{array}{l}\text { Assessment } \\
\text { Aspect }\end{array}$ & VI & V2 & V3 & V4 & V5 & V6 & V7 & V8 & $\boldsymbol{A}$ \\
\hline 1 & $\begin{array}{l}\text { Clarity of } \\
\text { evaluation } \\
\text { instructions }\end{array}$ & 4 & 4 & 5 & 5 & 4 & 5 & 5 & 4 & 4,5 \\
\hline 2 & $\begin{array}{l}\text { Clarity of the } \\
\text { steps of the } \\
\text { assessment } \\
\text { process }\end{array}$ & 5 & 4 & 5 & 5 & 5 & 5 & 5 & 5 & 4,87 \\
\hline 3 & $\begin{array}{l}\text { Clarity of } \\
\text { evaluation } \\
\text { time }\end{array}$ & 4 & 4 & 4 & 5 & 5 & 5 & 5 & 5 & 4,62 \\
\hline 4 & $\begin{array}{l}\text { Clarity of } \\
\text { how to score }\end{array}$ & 4 & 5 & 5 & 5 & 5 & 5 & 4 & 4 & 4,62 \\
\hline 5 & $\begin{array}{l}\text { Completeness } \\
\text { of the } \\
\text { contents of } \\
\text { the directories }\end{array}$ & 5 & 5 & 5 & 5 & 5 & 4 & 5 & 5 & 4,87 \\
\hline 6 & $\begin{array}{l}\text { The } \\
\text { effectiveness } \\
\text { of sentences }\end{array}$ & 4 & 4 & 4 & 5 & 5 & 5 & 5 & 5 & 4,62 \\
\hline 7 & $\begin{array}{l}\text { Use words } \\
\text { and } \\
\text { understandabl } \\
\text { e terms }\end{array}$ & 4 & 4 & 5 & 5 & 5 & 5 & 4 & 4 & 4,5 \\
\hline 8 & $\begin{array}{l}\text { Correct } \\
\text { spelling and } \\
\text { punctuation }\end{array}$ & 5 & 4 & 5 & 5 & 5 & 5 & 5 & 5 & 4,87 \\
\hline Font and size & 5 & 4 & 5 & 5 & 5 & 5 & 4 & 5 & 4,75 \\
\hline$A n$ & \multicolumn{2}{|c|}{ Average: } & & & & & 4,69 \\
\hline
\end{tabular}

Annotation: $\mathrm{V}=$ Validation

Based on Table II, all components of the evaluation directories achieved an average score of 4.69 , meaning that all components were very good

\section{2) Assessment for Process Evaluation Model Instrument}

The validation of the evaluation model instrument was divided into the lesson plan instrument (RPP), the classroom implementation instrument, and the achievement learning instrument. The strength of the instrument can be seen from the clarity of the instructions, the clarity of the indicators, the language and the grammar used. Elsewhere, clarity of scope includes (1) indicators of lesson plans (RPP) and assessment indicators. Besides, assessments of the language include (1) standard use of Indonesian, (2) communicative statements, and (3) sentences that are easy to understand and correct writing.

TABLE III. RESUlTS OF VALIDATION OF THE IPS LEARNING PROGRESS BY EXPERTS AND USERS

\begin{tabular}{|c|c|c|c|c|c|c|c|c|c|c|}
\hline No & $\begin{array}{c}\text { Assessment } \\
\text { Aspect }\end{array}$ & $V 1$ & $V 2$ & $V 3$ & $V 4$ & V5 & $V 6$ & $V 7$ & V8 & $A$ \\
\hline \multirow[b]{2}{*}{1} & Directories & & & & & & & & & \\
\hline & $\begin{array}{l}\text { Clarity of the } \\
\text { directories } \\
\text { instrument }\end{array}$ & 4 & 4 & 5 & 4 & 4 & 4 & 4 & 4 & 4,13 \\
\hline \multirow{4}{*}{2} & $\begin{array}{l}\text { Clarity of } \\
\text { indicators }\end{array}$ & & & & & & & & & \\
\hline & $\begin{array}{l}\text { Lesson Plan } \\
\text { Indicators }\end{array}$ & 4 & 4 & 4 & 4 & 4 & 4 & 4 & 4 & 4 \\
\hline & $\begin{array}{l}\text { Learning } \\
\text { Process } \\
\text { Indicators }\end{array}$ & 3 & 5 & 4 & 4 & 3 & 4 & 3 & 3 & 3,63 \\
\hline & $\begin{array}{l}\text { Assessment } \\
\text { Indicators }\end{array}$ & 4 & 5 & 4 & 5 & 4 & 4 & 4 & 3 & 4,13 \\
\hline \multirow{3}{*}{3} & $\begin{array}{l}\text { Clarity of } \\
\text { Research } \\
\text { Instrument }\end{array}$ & & & & & & & & & \\
\hline & $\begin{array}{l}\text { Direction of } \\
\text { Questioners }\end{array}$ & 4 & 4 & 4 & 4 & 4 & 4 & 4 & 4 & 4 \\
\hline & $\begin{array}{l}\text { The direction of } \\
\text { Observation } \\
\text { Sheet }\end{array}$ & 4 & 4 & 4 & 4 & 4 & 4 & 4 & 4 & 4 \\
\hline \multirow{5}{*}{4} & $\begin{array}{l}\text { Language and } \\
\text { Grammar }\end{array}$ & & & & & & & & & \\
\hline & $\begin{array}{l}\text { Clarity of } \\
\text { Sentences }\end{array}$ & 4 & 4 & 4 & 5 & 4 & 4 & 4 & 4 & 4,13 \\
\hline & $\begin{array}{l}\text { Understandable } \\
\text { Term and Word }\end{array}$ & 4 & 4 & 4 & 4 & 4 & 4 & 4 & 4 & 4,0 \\
\hline & Correct Writing & 4 & 4 & 4 & 4 & 4 & 4 & 4 & 4 & 4,0 \\
\hline & Font and Size & 3 & 4 & 4 & 4 & 3 & 4 & 3 & 3 & 4.62 \\
\hline \multicolumn{9}{|c|}{ Averange: } & \multicolumn{2}{|c|}{4,01} \\
\hline
\end{tabular}

\section{Annotation: $\mathrm{V}=$ Validation}

Based on Table III, all components of the learning process achieved an average score of 4.01, meaning that all components were very good and accepted without revision.

The IPS evaluation model, which was validated by experts and teachers, was further trialed at a several of Junior High Schools in Aceh. The results of the evaluation model are presented in Table IV below. 
TABLE IV. Results of Assessment of Evaluation Model

\begin{tabular}{|c|c|c|c|c|c|}
\hline \multirow[t]{2}{*}{ No } & \multirow[t]{2}{*}{$\begin{array}{c}\text { Assessment } \\
\text { Aspect }\end{array}$} & \multicolumn{3}{|c|}{ Trial Subject } & \multirow[t]{2}{*}{ Average } \\
\hline & & $\begin{array}{l}\text { Headm } \\
\text { aster }\end{array}$ & $\begin{array}{c}\text { School } \\
\text { Supervisor }\end{array}$ & $\begin{array}{c}\text { Teacher } \\
\mathrm{s}\end{array}$ & \\
\hline 1 & $\begin{array}{l}\text { Evaluation } \\
\text { Model } \\
\text { Directories }\end{array}$ & 4,38 & 4,29 & 4,13 & 4.26 \\
\hline 2 & $\begin{array}{l}\text { Lesson Plan } \\
\text { Instrument }\end{array}$ & 4,01 & 4,21 & 4,14 & 4.12 \\
\hline 3 & $\begin{array}{l}\text { Learning } \\
\text { Process } \\
\text { Instrument }\end{array}$ & 4,13 & 4,31 & 4,03 & 4.15 \\
\hline 4 & $\begin{array}{l}\text { Achievement } \\
\text { Instrument }\end{array}$ & 4,18 & 4,08 & 4,28 & 4.18 \\
\hline \multirow{2}{*}{\multicolumn{5}{|c|}{$\begin{array}{c}4,17 \\
\text { Averange }\end{array}$}} & \\
\hline & & & & & 4.18 \\
\hline
\end{tabular}

Based on the results of the assessment to evaluation models (Tabel IV), the Direction Evaluation Model obtained a very good category. Then the Lesson Plan IPS instrument got a good category, and the IPS Learning Process instrument was in a good category, then the IPS Learning assessment instrument got a good category too. The overall directories and evaluation models of the IPS learning program have an average score of 4.18 , meaning that the category is good, so it can be accepted to be used without revision

\section{ACKNOWLEDGMENT}

Thanks to LPPM Universitas Syiah Kuala, as the full funding provided for this research. We also thank the Department of Education in Banda Aceh for granted permission. Last, thanks to all research subjects and validators who have participated so well that this research was successfully carried out.

\section{REFERENCES}

[1] Azwar. Saifuddin, Reliability dan Validitas, Yogyakarta: Pustaka Belajar, 2012, p 52

[2] Creswell. J W, Research Design: Qualitative, Quantitative, and Mix Methods Approaches, 4th Ed, USA: SAGE Publication, 2014, p 97

[3] Ellis. Arthur K, Teaching and Learning Elementary Social Studies, 6th Ed, Massachusetts: Allyn and Bacon, 1998, p 2

[4] Gall. M, Gall. J P, Borg. W R, Educational Research, 8th Ed, New York: Pearson, p 775

[5] Mardapi. Djemari, Teknik Penyusunan Instrument Tes dan Non Tes, Yogyakarta: MitraCendekia, 2008

[6] Sarifudin. W, Konsep dan Masalah Pengajaran Ilmu Sosial di Sekolah Menengah, Proyek Pengembangan LPTK, Jakarta: Ditjen Dikti, p 15

[7] Widoyoko. E P, Teknik-teknik Penyusunan Instrumen Penelitian, Yogyakarta: Pustaka Pelajar, 2016, p 10

[8] Zamroni, "Pengajaran Ilmu-ilmu Sosial pada Era Globalisasi", Workshop membedah pemahaman ilmu-ilmu social, 13 October 200 